\title{
Algumas Verdades sobre o Tratamento Fisiátrico das Cervicalgias
}

R.E. de Araújo Leitão*

Henrique Ayres de Vasconcelos**

Valéria de Araujo Leitão**

* O emprego dos recursos fisiátricos no tratamento das cervicalgias têm a vantagem de encurtar ou de abolir o sofrimento do paciente. Além disso, os efeitos favoráveis contra os sintomas dolorosos revelam-se mais duradouros.

* As principais causas básicas das cervicalgias de origem reumática são a artrose, a discartrose, a hérnia discal, a costela cervical, as infecções piogênicas, a tuberculose vertebral e os tumores medulares.

* Lembre-se que a disfunção crânio-mandibular pode acompanhar-se de alterações anátomo-funcionais importantes que podem ser responsáveis por distúrbios posturais da cabeça e do pescoço e que portanto, deve ser incluída no diagnóstico diferencial das cervicalgias.

* De acordo com a opinião de vários especialistas brasileiros, a incidência das cervicalgias é ligeiramente mais alta nas mulheres do que nos homens e alcança a cifra de $4,1 \%$ entre os doentes reumáticos.

\footnotetext{
Médico da Academia Nacional de Medicina e da Academia de Medicina de Reabilitação

** Doutor em Anatomia pela USP, Mestre em Med. Fis. e Reabilitação pela UFRJ

*** Médico do Serviço de Fisiatria do Instituto de Neurologia Deolindo Couto - UFRJ
} 
* A razão primária das cervicalgias de causa mecânica encontra-se na compressão da raiz nervosa em razão da angústia do forâmen vertebral. Lembre-se que dois terços deste forâmen na coluna cervical são ocupados por tecido conjuntivo (mole); o restante é preenchido pela raiz nervosa e vasos sanguíneos.

* A tração vertebral, por vezes indicada no tratamento fisiátrico das cervicalgias de origem mecânica deve ser feita sem extensão da coluna cervical, mas peremptoriamente, em ligeira flexão.

* Quando o paciente sofre de disfunção têmporo-mandibular, a tração cervical requer grandes cuidados técnicos a fim de evitar maiores traumatismos sobre a articulação.

* A força de tração para alongamento da coluna cervical não deve ultrapassar os quinze quilos em um indivíduo adulto de 70 quilos e sua escolha e administração devem adaptar-se à tolerância do paciente. É absolutamente incorreto tracionar uma coluna cervical até alçar o paciente da cadeira onde se encontra sentado.

* A tração exagerada da coluna cervical apresenta riscos apreciáveis, mormente em pacientes idosos: por exemplo, ruptura de ligamento, fratura de vértebra, luxação vertebral, compressão medular...

* Visando a segurança adequada, a tração cervical deverá ser feita com o paciente sentado, recostado ou completamente deitado. Nunca em pé.

* A experiência mostra ser incoveniente administrar ondas curtas ou outras formas de calor profundo nas cérvico-braquialgias agudas de causa degenerativa ou metastática pois, o calor profundo determina a dilatação dos vasos sanguíneos e contribui para o aumento da compressão radicular.

* Os padecentes de cervicalgia devem usar travesseiro de consistência firme. (densidade da espuma em torno de 30 a 33) e altura (espessura) de aproximadamente dez a doze $\mathrm{cm}$. Evitar travesseiros muito baixos e moles.
* Os colchões usados por padecentes de reumatismo vertebral devem possuir consistência firme (densidade da espuma em torno de 28 a 33) a fim de evitar o aumento das curvaturas fisiológicas da coluna. Este tipo de colchão consegue retificar a coluna e beneficia a postura do paciente.

* O emprego indiscriminado da tração vertebral nas cervicalgias oferece riscos para o paciente; este recurso somente deve ser usado após um acurado exame clínico, feito corretamente por um fisiatra, um neurologista, um reumatologista ou um ortopedista com experiência no ramo. Acidentes graves podem ocorrer por falta de obediência a este princípio.

* Atenção especial para o emprego da manipulação vertebral. Existe risco para o doente, mormente nas cervicalgias causadas por compressão radicular (discartrose, hérnia de disco, osteofito no forâmen vertebral).

* A melhor conduta terapêutica inicial no tratamento fisiátrico das cervicalgias agudas são apenas o repouso, a imobilização do pescoço mediante o emprego de colar cervical, por exemplo, antiinflamatórios e miorelaxantes, antes de esclarecer completamente o diagnóstico.

* As órteses cervicais, (colares) ao promoverem restrição importante da mobilidade cefálica, não devem ser utilizadas durante longo período de tempo após as fases agudas e subaguda, pois têm o inconveniente de enfraquecer a musculatura do pescoço.

* Na postura de indivíduos deprimidos, pode observar-se uma anteriorização de cerca de $7 \mathrm{~cm}$ do segmento cefálico em relação ao centro de gravidade. Resulta daí um aumento de peso sobre a coluna cervical em torno de dez quilos, provocando assim cervicalgia. Portanto, é imperioso não esquecer também a correção postural em todos os pacientes, especialmente nestes últimos.

* A cinesioterapia pode alongar os músculos do pescoço e da nuca que estejam tensos e aliviar a 
dor nas cervicalgias. Por esta razão, ela costuma ter excelente indicação.

* O tratamento fisiátrico das cervicalgias deve incluir obrigatoriamente a avaliação biomecânica da coluna vertebral e o emprego de exercícios corretivos posturais, acompanhados do fortalecimento dos grupos musculares da região afetada.

* Aos portadores de cervicalgia aguda ou crônica, é recomendável evitar esforço de carregar pesos nas mãos, nos antebraços, especialmente se for necessário manter os cotovelos fletidos. 